\title{
THE IMPLEMENTATION OF WRITE-AROUND PLUS STRATEGY TO IMPROVE STUDENTS' WRITING SKILL
}

\author{
Muziatun \\ Department of English Language, Faculty of letters and culture, \\ State University of Gorontalo, Indonesia \\ Email: muziatun@ung.ac.id \\ Thalia Miranda Virginia \\ Department of English Language, Faculty of letters and culture, \\ State University of Gorontalo, Indonesia \\ Email: thalyavirginia96@gmail.com \\ Ansar Tario Jusuf \\ Department of English Language, Faculty of letters and culture, \\ State University of Gorontalo, Indonesia \\ Email: ansartario@gmail.com
}

\begin{abstract}
APA Citation: Muziatun., Virginia, T. M., \& Jusuf, A. T. (2020). The implementation of write-around plus strategy to improve students' writing skill. English Review: Journal of English Education, 8(2), 247-254. doi: 10.25134/erjee.v8i2.3001.
\end{abstract}

Received: 29-01-2020

Accepted: 20-03-2020

Published: 01-06-2020

\begin{abstract}
Writing ability is one of English skills that need to be mastered by students. It is because students must express their idea well in order those readers can easily understand what students write. Moreover, many students' problems are found in writing such as generating idea, lack of vocabulary, grammatical mistakes and so on. Regarding the occurrence of problem in mostly students' writing, the researchers want to improve students' writing skill in descriptive text by implementing write-around plus strategy. The purpose of conducting this research is to investigate whether the implementation of write-around plus strategy can improve students' writing skill or not. This study is conducted by a pre-experimental study with measurement as the technique of collecting the data and written test as the tool of collecting the data. The research participants were 25 students as the eighth grade students in junior high school SMP Negeri 1 Gorontalo in academic year 2018/2019. The result of this study shows that there were improvements in all writing aspects such as fluency, grammar, vocabulary, content and spelling. The improvements of students' writing can be shown by data analysis, namely the average result of the research for pre-test got 9.04 score and it currently has been increased in post-test about 13.4 score.
\end{abstract}

Keywords: write-around plus strategy; descriptive text; pre-experimental study.

\section{INTRODUCTION}

Students need to master writing skill because they can communicate and express their idea well so that the teacher will understand easily what those students write (Bakeer, 2018; Kusna, 2019; Maolida \& Salsabila, 2019; Namasivayam, Singh, Mostafa, Janoory, \& Abdullah, 2017). This idea is also supported by Nunan (2003) that writing is the mental work of inventing ideas, thinking about how to express them, and organizing them into statements and paragraph that will be clear to a reader. Although mostly students feel writing is a complicated skill (Karademir \& Gorgoz, 2019; Setyowati \& Sukmawan, 2016; Ximenes, Guterres, \& Pereira, 2019), but in fact both education curriculums in Indonesia between Curricuum 2013 and Kurikulum Tingkat Satuan Pendidikan (KTSP), the curriculums require those students are expected to have extensive knowledge in writing task. However, it is hard to teach in the beginner level students about how to write (Alharbi, 2019; Teng, 2019), because teachers should consider many components in teaching writing such as structure, vocabulary, content and spelling as the requirement of curriculums.

Moreover, many problems were found in teaching and learning writing (Astrini, Ratminingsih, \& Utami, 2020; Haerazi \& Irawan, 2019; Xie, 2020), such as generating idea, lack of vocabulary, grammatical mistakes, spelling mistakes etc. The same problems also found by researchers during teaching practice at SMP Negeri 1 Gorontalo as the junior high school in Gorontalo city. Mostly students at eighth grade were found difficulties in writing. First, the 
students have limited vocabularies to expand their sentences. Second, they found difficulties in generating ideas when they start writing a text. Third, they have a problem to use grammar well in formulating descriptive text. The last, the students have lack of motivation in learning writing because of inappropriate strategy and learning media in teaching process. This study wants to apply one of the elaboration appropriate learning strategies that have been believed to be able to increase students writing skills ability.

To overcome the problems of students' writing, more appropriate learning strategies in teaching writing should be implemented in junior high school. One of learning strategies is cooperative learning. Based on Piaget's theory, cooperative learning is an active and participatory learning strategy. This theory needs students' participation in learning activity. Therefore, it will make students more active and work in group (Kimmelmann \& Lang, 2019; Yusuf, Jusoh, \& Yusuf, 2019), so students will understand the learning material easily. One of the strategies from cooperative learning that useable to teach writing descriptive text is write-around (Munnisa, 2015). This strategy will improve students' skill and they can organize or arrange the sentence step by step as per the instruction of that strategy itself. By applying write-around as a learning strategy in a writing activity, the students will not only can learn how to write and organize the sentence in English, but they also can cooperate and communicate each other during the process of teaching and learning.

As the strategies explained before, cooperative learning means student's learning together in groups (Strom, Hendon, Strom, \& Wang, 2019), which are structured that group members have to cooperate succeed. Students learn their material in-group; also they will find and solve the problem of the material together. The concept of cooperative learning is teamwork (Asrori \& Tjalla, 2020; Salim, Abdullah, Haron, Hussain, \& Ishak, 2019; Strom et al., 2019). Students will interact with others and make small groups to be motivated and help one another to gain objectives of the study. According to Mandal (2009) cooperative learning is a successful teaching strategy in which small teams, each with students of different levels of ability, use a variety of learning activities to improve their understanding of a subject. Each member of a team is responsible not only for learning what is taught, but also for helping teammates learn. Thus, it is creating atmosphere of achievement. Based on
Mandal's research, there are many types of cooperative learning. They are think pair share, three steps interview, jigsaw, round robin, threeminute review, numbered heads, buzz groups, talking chip, critical debate, write-around and praise question polish. One of cooperative learning type that will be use is write-around strategy. The advantage of write-around strategy is that students will be easier to produce a text because they are not work individual but they will work in-group.

Write-around plus strategy is a development from previous research and modification of writearound strategy. The researchers make a new innovation in this strategy. This makes the previous study unique. Some studies that apply techniques and strategies in teaching and learning sometimes do not make some adjustments when applying such techniques and strategies. However, this study is different by doing some modifications to accommodate students' necessities. Therefore, the implementation of the new strategy could improve students' writing skill ability. The researchers try to teach from base of writing for beginner level. There are how to make simple sentence and learn word classes such as noun, adjectives and verbs that related to descriptive text and also how to make descriptive text complete.

In learning and teaching process, there are some steps that can be used by teacher in this study, in order to make students be more active. Following steps of write-around plus strategy:

- Teacher splits students into several groups; it will be 4-5 members in each group.

- Teacher chooses the topic that will write it

- Teacher gives starter sentence for all of the groups.

- Each student in-group will read a sentence and add another sentence to finish the text.

The strength of write-around plus strategy is beside this strategy has the concept of teamwork; this strategy also can help students to stimulate their mind to generate their idea in writing a sentence creatively.

The weakness of this strategy is taking a time a lot for student to understand what they want to write, because they need to understand the starter sentence or their friend's opinion before they write their own sentence. The reason why the researchers proposed this strategy was because of the purpose of write-around plus strategy as a bridge for students to share their idea. In order to create an interesting way to learn descriptive text, it is also so much fun strategies for students, 
because they do it in-group. Based on the background presented earlier, the research question for this paper is: Can write-around plus strategy improve students' writing skill in formulating a descriptive text?

\section{METHOD}

This study has been conducted at SMP Negeri 1 Gorontalo as one of educational institutions in Gorontalo city. It is pre-experimental design one group pretest and posttest design which is to be used in order to see the use of write-around strategy to improve students' writing skill in descriptive text based on the score before applying the strategy and the score after applying the strategy. The research participants were selected based on purposive sampling which is a technique to determine the sample of research with some consideration to make the data will be more representative. So the researchers consider the participants of this study were students at eighth grade at SMP Negeri 1 Gorontalo in academic year 2018/2019. Based on Curriculum 2013 , one of the materials learned by students in eighth grade is descriptive text. In this case, students in this level need to be able to make a descriptive text. So, there are some specific requirements are needed to filter the objectives for this research.

In SMP Negeri 1 Gorontalo academic year $2018 / 2019$, there are nine class of eighth grade. The researchers choose one class as the participants of this research, which is VIII-2 because the students are selected based on the requirement of primary observation with their English teacher at the school itself. There are 25 students selected as samples. Those 25 students have major problems in writing, such as lack of generate idea, grammatical errors, lack of vocabularies etc.

The researcher collected the data $\mathrm{b}$ using a test as the main method. The details of each instrument will be described next:

\section{Test}

The researcher used test as the main method in collecting the data because the researchers measured students' ability in writing. As mentioned earlier, students' ability can be measured by doing the test (Munnisa, 2015). Because brown (2004) states that a test can be defined as a method of measuring a person's ability, knowledge, or performance in a given domain. As the main method, it is an instrument a set of techniques, procedures, or items that require performance on the part of the test taker.
Overall, test will be conducted in order to know the students' achievement in learning process. There are two kinds of test that would be conducted in this study. They were pre-test and post-test, both tests will be explained further below.

\section{Pre test}

Pretest is preliminary test administered to determine a student's baseline knowledge or preparedness for an educational experience or course of study (Hamzah, 2016). It can be used before the teacher extends the material of learning. In this test the researchers gave the students a written test about descriptive text. The students would choose one topic and describe the topic itself.

\section{Treatment}

Treatment is activities from teacher to the students by giving teaching learning material in the class (Hamzah, 2016). This strategy is kind of way that can improve students' writing skill. The researchers taught in learning process during eight times of treatments by using write-around strategy. It is because eight times of treatments were suitable for students in order they can make an appropriate paragraph of descriptive. Besides that, it is also related with their schedule of academic for material about descriptive text.

\section{Post test}

Post-test was given after a lesson or a period of instruction to determine what students have learned. The researchers gave a written test again for the students in order to know how the improvement those students get after they have a treatment.

This research used quantitative data analysis. It is because the researcher used analyzing and assessing the students' work in pretest and posttest and give the score based on rubric assessment.

In this way, each student score in pre-test and post-test would have been compared in order to see the improvements of students' writing skill.

In scoring their work, the researchers used the scoring rubric in writing taken from Heaton Grid and his Categories (1975) in five areas, there are fluency, grammar, content, vocabulary and spelling. The researcher used Heaton's grid because some researchers used his grid as guide to assess test of writing.

Subsequently this study used statistical analysis, because the aim of this study was to see the comparison scores of pre-test and post-test. In analyzing the data the researcher used T-testing. 
It analyzed the hypothesis of this study as $\mathrm{H}_{1}$ : Write-around strategy can improve described below.

$t: \frac{\bar{D}}{S D}$

Notes:

$\mathrm{t} \quad=$ the value of $\mathrm{t}$ for correlated sample

$\bar{D} \quad=$ the amount of average differences

divide with the amount of sample

$\mathrm{SD}=$ Deviation standard differences divide with the amount of sample

Statistic hypothesis

$\mathrm{H}_{0} \quad$ : Write-around strategy cannot improve students' writing skill

$\mathrm{H}_{0} \quad: \mu_{1}=\mu_{2}$ it means rejected students' writing skill

$\mathrm{H}_{1} \quad: \mu_{1} \leq \mu_{2}$ it means received

\section{RESULTS AND DISCUSSION}

Pre-test

In the first meeting, the researchers conducted pre-test in order to find out students' ability in writing description text. The researcher asked students to choose one topic about one of family member, favorite place in Gorontalo or favorite thing to make simple descriptive text. After calculating the students' worksheet, the researcher found that the students' score of pretest data as follow:

Table 1. Students' score in pre-test

\begin{tabular}{ll}
\hline \multicolumn{2}{c}{ Students' score in pre-test } \\
\hline The lowest score & 5 \\
The highest score & 17 \\
The range of interval class (R) & 12 \\
The amount of interval class (K) & 6 \\
The wide of interval class (P) & 2 \\
The mean of score & 9.04 \\
\hline
\end{tabular}

Table 2. Students' components of writing score in pre-test

\begin{tabular}{ccc}
\hline No & Components of writing & The score of pre test \\
\hline 1 & Fluency & 46 \\
2 & Grammar & 36 \\
3 & Vocabulary & 42 \\
4 & Content & 41 \\
5 & Spelling & 61 \\
& Total & 226 \\
\hline
\end{tabular}

Based on the tables presented earlier, it shows that the highest interval class in 5-6 consisted of eight students. It means there were eight students who got 5-6 score in the pre-test. Furthermore, the lowest interval class was 13-14, 15-16 and 1718 consist of one student which means only one student who got score 13-17 score.

\section{Students' problem in pre test}

The result of pre-test show that many students were still confused to write descriptive text, students made some mistakes, dealing with the organization problems that students did not understand about the generic structure of descriptive text. For example, some students did not write clearly both identification and description. One of students in VIII-2 did not write clearly both identification and description. Especially in identification part, the student only mentioned the name of his favorite things without writing more information about his favorite thing while in the part of description, the student only wrote the general information and not the specific information of the thing that he described. In this case, student was expected to be able to write more information about his favorite thing.

Students also made some grammatical problems, such as the using of simple present tense as the main tense in descriptive text. For the example, the student wrote "I was use my computer". The word "was" is inappropriate because it is past participle. In this case the student is expected to be able to write "I use".

Students also got problem in using of vocabulary. The student had lack of vocabulary and also made some errors in expressing his idea such as "television shape, television color". It should be changed become "the color of television" and "the shape of television".

The last aspect of writing is mechanic. Some students of the second grade of SMP Negeri 1 Gorontalo have problems in spelling the words. They understood to use the words but they got some errors to spelling it into written form. The 
words "thirteen five years old, thirteen nine years old, and fother" were incorrect spelling. It should be changed "thirteen five years old" become "thirty-five", "thirteen nine years old" become "thirty-nine" and "fother" become "father".

\section{The description of treatments}

In pre-test, students faced several problems in their writing forms. During the treatments, students have improved their writing form. There are some explanations of the situation when the researchers did the treatments in the classroom:

In the first meeting, students learned about definition of descriptive text and the example of descriptive text. This meeting students only paid attention to what the researchers had explained and the students understood about descriptive text.

The second meeting, the researchers explained more about descriptive text such as the generic structure of descriptive text and the language features of descriptive text. From first meeting until second meeting some students confused about the material, because when the researcher asked to the students to give another example of descriptive text, some of them did not give the answer. Then, the researcher explained more about descriptive text and the students understood about that.

Next to the third meeting, the researchers started applying write-around plus strategy in classroom. Before that, the researchers split students into several groups and the researchers explained about the rule of write-around plus strategy. Then, the researchers separated the students into five groups. After that, the researcher explained about word class as the use of adjective in descriptive text. By using writearound plus strategy, the researcher gave them the first task in group to write a simple sentence using adjectives each person in group. All students in VIII-2 felt enjoy when they did their task because they could discuss how to make a simple sentence using adjective with their friends in group or the researcher as teacher in the class.

Then fourth treatment, the researcher explained about grammar that use in descriptive text, it was about simple present tense. Students were divided into same group and the researcher explained about simple present tense. The researcher gave them task to make simple sentence based on simple present tense by using write-around plus strategy. Some students confused about the use of simple present tense and they asked to the researchers. After the researchers explained more about simple present tense, they understood and they finished their task.

Fifth meeting, the researcher explained again about simple present tense. Besides that, the researcher reviewed about the generic structure of descriptive text, because students started making a simple descriptive text about favorite place in Gorontalo. The researchers asked students in each group to discuss about the place that they want to describe. Then, the researcher gave them sentence starter: my favorite place in Gorontalo is..." Then, the first person in group wrote name of place and continue wrote his/her opinion in a sentence about that place. The second person continued to write her/his opinion in a sentence and until last person to finish the task. Actually, some students had lack of ideas to write their opinion in a sentence. So, the researchers tried to help them to guide what they need to write in their simple descriptive text.

Next in the sixth meeting, the researches explained about the use of have/has. Students paid attention with the researchers' explanation. The students were still in their groups. After that, the researcher gave the topic to the students about my friend/classmate. The researcher gave sentence starter "I have a friend, my friend's name is". The way to finish their task was same with the one in the fifth meeting. In sixth meeting, some students in group understood what they want to write. So, the researcher did not to guide them again. Some students also sometime asked to the researcher about some words that they did not know. Students in each group could finish their task well.

Come to the seventh meeting, the researcher reviewed and explained about the use of have/has. It made students still understand about how to use have/has. In this meeting, students were still in their group and made simple descriptive text about favorite thing. For this topic, students in group choose the thing that they need to describe. The researcher gave them some pictures about things; there were bag, doll, shoes, clothes, book and pencil. Every group chooses a thing that they want to describe. As usual, the researcher gave a sentence starter "I have a..." Then, the students continued to give their opinion in a sentence until the last person in group. In this meeting, all of students felt enjoy when they did their task, because they know what they wrote for that thing. Each group did their task well done.

The last meeting, the researcher rechecked again their previous tasks. When doing 
rechecked, the researcher found significant improvement on students' tasks. It can show that there was one of group, their tasks were developed their simple descriptive text. Then, the researchers gave appreciation to all of students VIII-2. After that, the researchers did brainstorming and reviewed all material about descriptive text to prepare students for post-test.

\section{The description of post-test data}

After scoring the students' worksheet in post-test, the researchers found that the students' score of post-test have been improved. The lowest score of post-test was six score. The highest score was 20 score and the mean of score was 13.4 score.

Furthermore, the results of post-test in each component of writing have improved the result of pre-test. There were for fluency and vocabulary aspect was 64 score, the grammar aspect got 60 score, the content was 69 score and for spelling aspect got 78 score.

Based on explanation about the result of pretest and post-test, students' ability in pre-test and post-test have been improved. The significant differences came from content aspect. In content aspect, students only got 41 score but in post-test students got 69 score. Content aspect becomes increase because they paid attention with the generic structure of descriptive text and they can generate their idea to make descriptive paragraph. Grammar aspect and vocabulary aspect also have significant differences. In grammar aspect students only got 36 score in pre-test, but in posttest students got 60 score. Grammar aspects also increase because they put their attention about simple present tense as the language feature of descriptive text.

\section{The effect of write-around plus strategy in students' writing descriptive text}

In last meeting, the writer gave post-test to students and it showed that there was a significant improvement especially in organization, grammar and vocabulary aspect compared the score result of pre-test and post-test. It was clearly different.

For example, in student's answer, the student already understood about the generic structure of descriptive text because he could organize it well. In this following student's answer, he only made an error in the use of word "is". This word should be "are", because the favorite food of character that he has been described was plural.

From this example, in student's written form, only a few errors that contain in this paragraph, for example the word "things" should be "thing", because it is singular and then words "searching, chatting, playing and listening" should be "search, chat, play and listen", because descriptive text use simple present tense.

Based on some example of students' answer, it can be concluded that by applying write-around plus strategy, students could understand and know how to make a descriptive text well. The students had given sentence starter then they were continuing to produce a text by making sentence by sentence in their group. Then, they were combined the sentences to be good descriptive text. Munnisa (2015) stated that write-around strategy could help students learn how to write descriptive text and make it enjoyed in class. Write-around strategy is very useful for students to help them in process of writing.

Descriptive text is a text with a purpose to describe particular thing, animal, person or other. The generic structure of descriptive text divided into two: identification and description (Gerot and Wignel, 1994). Besides the generic structure, descriptive text also has own language features that should be mastered by the writers. The language features of descriptive text are: focus on specific participant, the use of adjectives and compound adjective, the use of linking verb, the use of degree comparison, the use of simple present tense (Munnisa, 2015).

Based on pre-observation, all of students in VIII-2 cannot write an appropriate descriptive text, they faced the difficulties to generate their ideas about the generic structure of descriptive text. They also have lack of vocabularies and difficulties in expressing their idea by using simple present tense. Therefore, in order to solve the problem, the researcher gave the treatment to students by using write-around plus strategy.

As we concern that the education in Indonesia applying 2013 curriculum, which is emphasizes to the students to learn contextually. In a class, there are many kinds of students' ability. Teacher should have a learning strategy to teach students contextually, however students in a class have many kinds of students' ability. Therefore, cooperative learning strategy can fulfill the aim of 2013 curriculum. As stated by (Mandal, 2009) cooperative learning is a successful teaching strategy in which small teams, each with students of different levels of ability, use a variety of learning activities to improve their understanding ofa subject. One of strategies in cooperative learning is write-around strategy.

By applying the strategy, the students could understand and remember how to write 
descriptive text. The students choose the topic that they want to write in group. After that, the students are given a starter sentence then they continue producing a text by making sentence by sentence with their group. Then, they combine the sentences to be a good paragraph. After making the descriptive text, the students discussed with their group and memorized what they would write in producing descriptive text. The impact of this implementation is the students can increase their group learning activity.

After researcher gave the treatment by using write-around plus strategy during the eight meetings, students have shown significant improvement on their writing ability. It has been proved in the result of post-test. In post-test, the researcher gave in the last meeting, which showed that there were significance improvements of the students' work especially in organization, grammar and vocabulary aspect. The comparisons of the result of pre-test and post-test were clearly different. Based on Munnisa (2015) stated that write-around is appropriate strategy in teaching writing. Therefore, write-around plus strategy is suitable for teaching writing descriptive text.

The result of $t_{\text {test }}$ from pre-test and post-test also have shown the difference that between $t_{\text {count }}$ and $t_{\text {list. }} \mathrm{t}_{\text {count }}$ is more than $\mathrm{t}_{\text {list }} 6,79 \geq 1,711$. Based on the data above, it can be said that Writearound Plus Strategy can improve students' ability in writing descriptive text. This statement also has been supported by Munnisa (2015) who stated that write-around strategy could improve students' writing skill, because the result can make students mastering vocabulary, adjective and structure in descriptive text. Students also have ability to gain their idea. Write-around strategy promotes group learning activity that can make students enjoyable when using write-around strategy.

\section{CONCLUSION}

Using write-around plus strategy is an effective way to teach students in improving students' writing in descriptive text. It is because students become more encourage in writing, will being motivated to each other, paying more attention during the learning process, students will have so much fun and even the teacher will have enthusiasm in teaching process. It can be proven from the result of pre-test and post-test that presented earlier. The result of students' improvement in writing ability to write descriptive text can be seen from the increasing of students' mean writing score from 9,04 in the pre- test to 13,4 in the post-test. The use of writearound plus strategy as a teaching strategy that is applied in teaching descriptive text considers as an effective strategy. It can be seen from the result effect of treatment phase. Write-around plus strategy using teamwork in learning process makes students will be more responsible, not only for learning but also for helping teammates to learn and creating atmosphere of achievement.

\section{REFERENCES}

Alharbi, M. A. (2019). Saudi Arabia EFL university students' voice on challenges and solution in learning academic writing. Indonesian Journal of Applied Linguistics, 8(3), 576-587.

Asrori, M., \& Tjalla, A. (2020). Increasing teamwork capacity of high school students through collaborative teamwork learning. American Journal of Educational Research, 8(1), 46-50.

Astrini, F., Ratminingsih, N., \& Utami, I. (2020). The model of strategies employed by English teachers in teaching writing skill in national plus schools. Journal of Education Research and Evaluation, 4(1), 59-62.

Bakeer, A. M. (2018). Effects of information and communication technology and social media in developing students' writing skill: A case of AlQuds Open University. International Journal of Humanities and Social Science, 8(5), 45-53.

Baliya, R. (2013). Enhancing writing abilities of primary class students through cooperative learning strategies: an experimental study. Journal of Behavioral Social and Movement Science, 2(1), 294-305

Boardman, C. A. (2001). Writing to communicate (2nd ed.). New York: Distance Learning Center.

Boardman, C. A., \& Frydenberg, J. (2002). Writing to communicate. New York: Pearson Education.

Brown, D. H. (2001). Teaching by principles: An interactive approach to language pedagogy (2nd ed.). New York: Addison Wesley Longman, Inc.

BSNP. (2016). Peraturan menteri pendidikan dan kebudayaan Republik Indonesia Nomor 024 Tahun 2016 tentang kompetensi inti dan kompetensi dasar pelajaran pada kurikulum 2013 pada pendidikan dasar dan pendidikan menengah. Jakarta: Badan Standar Nasional Pendidikan.

Gerot, L., \& Wignell, P. (1994). Making sense of functional grammar. Sydney: Gerd Stabler.

Griffee, D. T. (2012). An introduction to second language research methods. New York: TESL-EJ Publications.

Haerazi, H., \& Irawan, L. A. (2019). Practicing genrebased language teaching model to improve students' achievement of writing skills. Indonesian Journal of English Language Teaching and Applied Linguistics, 4(1), 9-18. 
Hamzah, N. S. (2016). The use of sense (simple present tense) word wall in increasing students' ability in writing descriptive text. Gorontalo: State University of Gorontalo.

Harmer, J. (2001). The practice of English language teaching. New York: Longman.

Husna, L, Zainil, \& Rozimela, Y. (2013). An analysis of students' writing skill in descriptive text at grade XIIPA 1 of MAN 2 Padang. Journal English Language Teaching, 1(2), 1-16.

Huy, N. T. (2015). Problems affecting learning writing skill of grade 11 at thong linh high school. Asian Journal of Educational Research, 3(2), 53-69.

Karademir, C. A., \& Gorgoz, S. (2019). English teachers' problems encountered in teaching four basic language skills. International Education Studies, 12(4), 118-127.

Kimmelmann, N., \& Lang, J. (2019). Linkage within teacher education: Cooperative learning of teachers and student teachers. European Journal of Teacher Education, 42(1), 52-64.

Kusna, S. S. (2019). Using picture prompts to improve student's writing skill in narrative text (an action reseach at the tenth graders of sma plus al amanah bojonegoro in the academic year of 2018/2019). IKIP PGRI Bojonegoro.

Mandal, R. R. (2009). Cooperative learning strategies to enhance writing skill. The Modern Journal of Applied Linguistics, 1(2), 94-102.

Maolida, E. H., \& Salsabila, V. A. (2019). Integrating process-genre approach with project ibunka to improve students' English writing. English Review: Journal of English Education, 8(1), 91100

Munnisa, T. (2015). The use of write-around strategy to improve students writing skill of descriptive text. Semarang: Semarang State University.

Namasivayam, P., Singh, C. K. S., Mostafa, N. A., Janoory, L., \& Abdullah, M. S. (2017). Improving ESL students' descriptive writing through wh-question technique. International
Journal of Academic Research in Business and Social Sciences, 7(7), 219-231.

Nunan, D. (2003). Practical English language teaching. New York: The Mc-Grew Hill Companies.

Salim, K., Abdullah, M., Haron, H., Hussain, N., \& Ishak, R. (2019). A team-teaching model in an informal cooperative learning classroom. International Journal of Emerging Technologies in Learning (iJET), 14(20), 44-57.

Setyowati, L., \& Sukmawan, S. (2016). EFL Indonesian students' attitude toward writing in English. Arab World English Journal, 7(4), 365378.

Strom, P. S., Hendon, K. L., Strom, R. D., \& Wang, C. H. (2019). How peers support and inhibit learning in the classroom: Assessment of high school students in collaborative groups. School Community Journal, 29(2), 183-202.

Siahaan, J. (2013). An analysis of students' ability and difficulties in writing descriptive texts. Journal of English and Education, 1(1), 114-121.

Teng, F. (2019). Tertiary-level students' English writing performance and metacognitive awareness: A group metacognitive support perspective. Scandinavian Journal of Educational Research, 64(4), 1-18.

Xie, Q. (2020). Diagnosing linguistic problems in English academic writing of university students: An item bank approach. Language Assessment Quarterly, 17(2), 183-203.

Ximenes, L. P., Guterres, C. F., \& Pereira, S. (2019). A study on the ability of 4th semester students' writing skill of English study program in the academic year 2018. ISCE: Journal of Innovative Studies on Character and Education, 3(1), 155164.

Yusuf, Q., Jusoh, Z., \& Yusuf, Y. Q. (2019). Cooperative learning strategies to enhance writing skills among second language learners. International Journal of Instruction, 12(1), 13991412. 